\title{
Study of the nutritional value of fermented milk drinks from goat's milk
}

\author{
Alma Shunekeyeva ${ }^{1, *}$, Mariam Alimardanova ${ }^{2}$, and Alexander Majorov ${ }^{3}$ \\ ${ }^{1}$ Shokan Ualikhanov Kokshetau University, Abay, 76, Kokshetau, 040000, Kazakhstan \\ ${ }^{2}$ Almaty Technological University, Almaty, Republic of Kazakhstan \\ ${ }^{3}$ Federal Altai scientific center of agro biotechnologies, Barnaul, Russian Federation
}

\begin{abstract}
The primary aim of this paper is to explore the nutritional value of fermented milk drinks from a goat. A vegetable component was used as fillers, including amaranth flour, flour from kumarshik, fruit and berry filler: irga, black chokeberry, and black currant. This study's specific objectives were to determine organoleptic and safety indicators and study the shelf life of finished fermented milk drinks from goat milk with various fillers. A detailed technological scheme for the production of fermented milk drinks was drawn up. In the study, the rational formulation of fermented milk drinks was determined using the "Search for solutions" program MS Excel.
\end{abstract}

\section{Introduction}

Recent trends in healthy food have led to a growing academic interest in the nutritional value of products. Nutritional value is a concept that reflects the full completeness of the useful properties of a food product, including the degree of meeting the physiological needs of a person in basic nutrients, energy, and organoleptic qualities. It is characterized by the chemical composition of the food product, taking into account its consumption in generally accepted quantities [1].

Calculation of nutritional value is carried out for $100 \mathrm{~g}$ of a fermented milk drink with a fruit and berry component, by calculation, depending on the raw materials.

The energy value is the amount of energy formed during the biological oxidation of fats, carbohydrates, and proteins in the product [1].

The energy value (EV) of a food product is calculated using the formula 1:

$$
\mathrm{EV}=\mathrm{P} \times 4.0+\mathrm{F} \times 9.0+\mathrm{C} \times 4.0+\mathrm{OA} \times 3.0,
$$

where EC is the energy value of $100 \mathrm{~g}$ of food, kcal;

Content in g / 100 g of product:

$\mathrm{P}$ - proteins, F - fats, C - carbohydrates, OA - organic acids;

The number of kcal formed during the combustion of food substances:

$\mathrm{P}=4.0 \mathrm{kcal} ; \mathrm{F}=9.0 \mathrm{kcal} ; \mathrm{C}=4.0 \mathrm{kcal} ; \mathrm{OA}=3.0 \mathrm{kcal}$.

\footnotetext{
*Corresponding author: a.shunekeyeva@kgu.kz
} 
The digestibility of nutrients depends on their ability to be absorbed from the gastrointestinal tract. The quantitative absorption capacity (digestibility coefficient) is expressed as a percentage of the total content of a given food substance in a product or diet. With a mixed (consisting of animal and plant products) diet, the coefficient of assimilation of proteins is on average $84.5 \%$, fats - $94 \%$, carbohydrates (the sum of digestible and indigestible carbohydrates) - 95.6\% [1].

The energy value (EC) of a food product, taking into account the coefficients of assimilation of nutrients, is calculated according to formula 2 :

$$
\mathrm{EV}=0.845 \times \mathrm{P} \times 4.0+0.94 \times \mathrm{F} \times 9.0+0.956 \times \mathrm{C} \times 4.0+\mathrm{OA} \times 3.0
$$

Energy values are calculated per $100 \mathrm{~g}$ of food and are expressed in kilocalories and kilojoules [1].

\section{Materials and methods}

Research objects: raw material - goat milk (Zaanen breed), vegetable fillers, finished products: fermented milk drinks from goat milk with fillers.

\section{Technological process}

Reception and preparation of milk. Milk and raw materials used in producing a fermented milk drink are taken according to the quantity and quality established by the enterprise's laboratory. The milk is weighed, cleaned from mechanical impurities in separators - milk purifiers and a deaerator, to remove extraneous tastes and odors. It is recommended to warm milk up to $30{ }^{\circ} \mathrm{C}-40{ }^{\circ} \mathrm{C}$ before filtering (Kryuchkova, 2018) [4].

Normalization. Goat milk selected for quality is normalized in terms of fat content. Part of raw purified milk, preheated to a temperature of $(42 \pm 3){ }^{\circ} \mathrm{C}$, is sent to a cream separator. The cream obtained during milk separation is pasteurized at a temperature of $(88 \pm 2){ }^{\circ} \mathrm{C}$, cooled to a temperature of $(4 \pm 2){ }^{\circ} \mathrm{C}$ and sent for storage, or immediately sent for processing at a temperature of $(42.5 \pm 2.5){ }^{\circ} \mathrm{C}$. The fat mass fraction and acidity are determined in the cream. Skimmed goat milk is pasteurized at a temperature of $(76 \pm 2){ }^{\circ} \mathrm{C}$ with an exposure of $(18 \pm 2) \mathrm{s}$, cooled to a temperature of $(4 \pm 2){ }^{\circ} \mathrm{C}$ and sent to a transitional storage tank, or immediately sent for processing at a temperature of (42 \pm 3$)^{\circ} \mathrm{C}$ (Kryuchkova, 2018) [4].

The mixture is normalized by the mixing method. In this case, the mass of products for mixing is determined by the formulas of the material balance or by the recipe so that the mass fraction of fat and dry matter in the finished product is not less than the mass fraction of fat and dry weight stipulated by the technical specifications (Kryuchkova, 2018) [4].

The normalized mixture is first heated to a temperature of $(60 \pm 5){ }^{\circ} \mathrm{C}$. Then the mixture is subjected to pasteurization (in a pasteurization unit) at a temperature of $(85 \pm 2)^{\circ} \mathrm{C}$ with a holding time of 8 to 10 minutes, or $90{ }^{\circ} \mathrm{C}$ with a holding time of 20 seconds. With the selected heat treatment mode, the best conditions are created for the destruction of unwanted microflora. The pasteurized normalized mixture is cooled to the fermentation temperature - from $40{ }^{\circ} \mathrm{C}$ to $42^{\circ} \mathrm{C}$ (Kryuchkova, 2018) [4].

Further, the pasteurized normalized mixture is subjected to ozonation for 10 minutes at an ozone concentration of $80 \mathrm{mg} / \mathrm{m}^{3}$; due to ozonation of goat milk, it turns out to increase the microbiological safety and taste characteristics of fermented milk drinks from goat milk.

Then milk was fermented by introducing thermophilic lactic acid bacteria and bifidobacterium Bifidobacterium lactis into ozonized milk. The duration of fermentation when using cultures of thermophilic lactic acid sticks (Lactococcus lactis subsp.lactis, Lactococcus lactis subsp.cremoris, Lactococcus lactis subsp.diacetilactis), and bifidobacteria Breve B 10, Bifidobacterium adolescentis B 14, Bifidobacterium adolescentis 
$B 37$ in a ratio of $2: 1$ ) is from 8 to 10 hours at a temperature of $37^{\circ} \mathrm{C}$ to $39{ }^{\circ} \mathrm{C}$ (Kryuchkova, 2018) [4].

The tank is filled with the mixer's mix to mix the mixture with the starter culture better. Stirring is finished 15 minutes after filling the reservoir. Then, herbal components are added to the prepared homogenized mixture:

1 - black currant, chokeberry, irga. The mix of fruit fillers is ozonized for 10 minutes before adding to the drink at an ozone concentration of $85 \mathrm{mg} / \mathrm{m}^{3}$ (Shunekeeva and Alimardanova, 2020) [2].

2 - flour from kumarshik and amaranth. A mixture of kumarshik flour and amaranth was ozonized for $10 \mathrm{~min}$ before adding to the drink at an ozone concentration of $115 \mathrm{mg} / \mathrm{m}^{3}$ (Shunekeeva and Alimardanova, 2020) [3].

They are added to a mixing vessel for even distribution. Stirring continues for 5 minutes to 7 minutes. Due to the use of ozonation of vegetable fillers, organoleptic characteristics are increased; the shelf life of drinks is extended to 14-15 days.

The mixture is fermented at a temperature from $40^{\circ} \mathrm{C}$ to $45^{\circ} \mathrm{C}$ until a tender, sufficiently dense curd is formed, without signs of separation of whey with an acidity of about $90^{\circ} \mathrm{T}$ or $\mathrm{pH}$ from 4.4 to 4.2 units (acidity is slightly lower than in the finished product). The clot's ripening is carried out at a temperature of $12-14{ }^{\circ} \mathrm{C}$ and lasts from 6 to 8 hours (Kryuchkova, 2018) [4].

After fermentation, the product is pumped to a tubular cooler, where it is cooled to a temperature of $30^{\circ} \mathrm{C}$ to $32{ }^{\circ} \mathrm{C}$.

Next, bottles made of polymeric and combined materials of various capacities (from 200-500 ml) were packaged, the resulting fermented milk drinks were cooled to a temperature of $(4 \pm 2){ }^{\circ} \mathrm{C}$, where they are stored until sale in refrigerating chambers (Kryuchkova, 2018) [4].

\section{Results and discussion}

In terms of organoleptic characteristics, the product must meet the requirements specified in table 1.

Table 1. Organoleptic characteristics of fermented milk drinks from goat milk with vegetable fillers

\begin{tabular}{|l|l|l|}
\hline Indicator name & \multicolumn{1}{|c|}{$\begin{array}{c}\text { Characteristic of the } \\
\text { fermented milk drink made from goat } \\
\text { milk with a fruit and berry component }\end{array}$} & \multicolumn{1}{|c|}{$\begin{array}{c}\text { Characteristic of the } \\
\text { goat milk cereal drink }\end{array}$} \\
\hline Consistency & $\begin{array}{l}\text { Homogeneous, with a broken clot with } \\
\text { filler inclusions. Slight separation of } \\
\text { whey is allowed }\end{array}$ & $\begin{array}{l}\text { Thick, homogeneous, with the } \\
\text { inclusion of cereal filler }\end{array}$ \\
\hline Taste and smell & $\begin{array}{l}\text { Pure, fermented milk, a taste of the } \\
\text { added filler }\end{array}$ & $\begin{array}{l}\text { Pure, fermented milk, with the taste of } \\
\text { added filler }\end{array}$ \\
\hline Color & $\begin{array}{l}\text { Light purple, uniform throughout the } \\
\text { mass }\end{array}$ & Creamy, uniform throughout the mass \\
\hline
\end{tabular}

In terms of physical and chemical indicators, fermented milk drinks from goat milk with vegetable fillers must meet the requirements specified in Table 2. 
Table 2. Physical and chemical characteristics of fermented milk drinks from goat milk with vegetable fillers

\begin{tabular}{|l|l|}
\hline \multicolumn{1}{|c|}{ Indicator name } & \multicolumn{1}{c|}{ Norm } \\
\hline Mass fraction of fat, $\%$ & $0 ; 1.0 ; 2.5 ; 3.2$ \\
\hline Mass fraction of protein,\% & 2.8 \\
\hline Mass fraction of sucrose, $\%$ & 2.0 \\
\hline Acidity, ${ }^{\circ} \mathrm{T}$ & 90 to 120 inclusive \\
\hline Phosphatase & Absent \\
\hline${\text { The temperature when leaving the factory, }{ }^{\circ} \mathrm{C}, \text { no more }}$ & $4 \pm 2$ \\
\hline
\end{tabular}

In terms of microbiological indicators, the product must comply with the requirements of the technical regulations of the Customs Union TRCU 021/2011 "On safety of food products" and the technical regulations of the Customs Union TR CU 033/2013 "On the safety of milk and dairy products," given in Table 3 (TR CU 021/2011..., 2011; TR CU 033/2013..., 2013) [6,7].

Table 3. Microbiological indicators of fermented milk drinks from goat milk with vegetable fillers

\begin{tabular}{|c|c|c|}
\hline \multicolumn{2}{|r|}{ Indicator name } & Norm \\
\hline \multicolumn{2}{|c|}{$\begin{array}{l}\text { The number of lactic acid bacteria at the end of the shelf life, CFU/ } \mathrm{cm}^{3} \\
\text { (g), not less }\end{array}$} & $10^{7}$ \\
\hline \multirow{3}{*}{$\begin{array}{l}\text { Product mass }\left(\mathrm{cm}^{3}, \mathrm{~g}\right) \text {, in } \\
\text { which it is not allowed }\end{array}$} & Escherichia coli bacteria & 0.01 \\
\hline & Staphylococcus aureus & 1.0 \\
\hline & $\begin{array}{l}\text { Pathogenic microorganisms, incl. } \\
\text { salmonella }\end{array}$ & 25.0 \\
\hline \multicolumn{2}{|c|}{ The amount of mold fungi, CFU / $\mathrm{cm}^{3}$ (g), no more } & 50 \\
\hline \multicolumn{2}{|c|}{ Yeast amount, CFU $/ \mathrm{cm}^{3}(\mathrm{~g})$, no more } & 50 \\
\hline \multicolumn{2}{|l|}{ Microscopic specimen } & $\begin{array}{l}\text { Chains of cocci, } \\
\text { regular-shaped sticks }\end{array}$ \\
\hline
\end{tabular}

Fermented milk drink with fruit and berry filling

The energy value $\mathrm{K}$, kcal, of the product, is (average values):

1. Fermented milk drink with fruit and berry filling 3.2\% fat, is equal to:

$$
\begin{gathered}
\mathrm{EV}=0.845 \times 3.2 \times 4.0+0.94 \times 3.2 \times 9.0+0.956 \times 7 \times 4.0+0.02 \times 3.0=10.816+27.072+ \\
26.768+0.06=64.716 \mathrm{kcal} .
\end{gathered}
$$

Energy value $\mathrm{K}, \mathrm{kJ}$, of the product, is equal to:

$$
64.716 \mathrm{kcal} \times 4.184=270.77 \mathrm{~kJ} \text {. }
$$

2. Fermented milk drink with fruit and berry filling $2.5 \%$ fat, is equal to:

$$
\begin{gathered}
\mathrm{EV}=0.845 \times 3.2 \times 4.0+0.94 \times 2.5 \times 9.0+0.956 \times 7 \times 4.0+0.02 \times 3.0=10.816+21.15+ \\
26.768+0.06=58.794 \mathrm{kcal}
\end{gathered}
$$

Energy value $\mathrm{K}$, kJ, of the product, is equal to:

$$
58.794 \mathrm{kcal} \times 4.184=246.0 \mathrm{~kJ} \text {. }
$$

3. Fermented milk drink with fruit and berry filler $1.0 \%$ fat, is equal to:

$$
\begin{gathered}
\mathrm{EV}=0.845 \times 3.2 \times 4.0+0.94 \times 1.0 \times 9.0+0.956 \times 7 \times 4.0+0.02 \times 3.0=10.816+8.46+ \\
26.768+0.06=46.104 \mathrm{kcal} .
\end{gathered}
$$


Energy value $\mathrm{K}, \mathrm{kJ}$, of the product, is equal to:

$$
46.104 \times 4.184=192.9 \mathrm{~kJ} .
$$

4. Sour milk drink with fruit and berry filling, low-fat, is equal to:

$\mathrm{EV}=0.845 \times 3.2 \times 4.0+0.94 \times 0 \times 9.0+0.956 \times 7 \times 4.0+0.02 \times 3.0=10.816+26.768+0.06=$ $37.65 \mathrm{kcal}$

Energy value $\mathrm{K}, \mathrm{kJ}$, of the product, is equal to:

$$
37.65 \mathrm{kcal} \times 4.184=157.5 \mathrm{~kJ} .
$$

Table 4 displays macronutrients' data on the component composition of fermented milk drinks of different fat content with a vegetable filler.

Table 4. Composition and energy value of fermented milk drinks from goat milk with fruit and berry filling

\begin{tabular}{|l|c|c|c|c|}
\hline \multicolumn{1}{|c|}{ Product name } & $\begin{array}{c}\text { Fat, } \\
g\end{array}$ & $\begin{array}{c}\text { Protein, } \\
g\end{array}$ & $\begin{array}{c}\text { Carbohydrates } \\
, g\end{array}$ & $\begin{array}{c}\text { Energy } \\
\text { value, kcal / } \mathrm{kJ}\end{array}$ \\
\hline $\begin{array}{l}\text { Fermented milk drink with fruit and } \\
\text { berry filling 3.2\% fat }\end{array}$ & 3.2 & 3.2 & 7.0 & $64.71 / 270.77$ \\
\hline $\begin{array}{l}\text { Fermented milk drink with fruit and } \\
\text { berry filling 2.5\% fat }\end{array}$ & 2.5 & 3.2 & 7.0 & $58.8 / 246.0$ \\
\hline $\begin{array}{l}\text { Fermented milk drink with fruit and } \\
\text { berry filler 1.0\% fat, }\end{array}$ & 1.0 & 3.2 & 7.0 & $46.1 / 192.9$ \\
\hline $\begin{array}{l}\text { Fermented milk drink with fruit and } \\
\text { berry filling, low-fat }\end{array}$ & 0.0 & 3.2 & 7.0 & $37.6 / 157.5$ \\
\hline
\end{tabular}

The product contains all the macronutrients necessary for the human body. As can be from Tables 4 and 5, the product contains mostly carbohydrates.

The digestibility of carbohydrates is very high; therefore, these fermented milk drinks can be considered a useful energy source for its consumers.

By a similar method, the energy value for the national milk-cereal drink made from goat's milk was calculated; the results obtained are shown in Table 5.

Table 5. Composition and energy value of milk-cereal drinks made from goat milk

\begin{tabular}{|l|l|l|l|l|}
\hline Product name & Fat, $g$ & Protein, $g$ & $\begin{array}{l}\text { Carbohydrates, } \\
\mathrm{g}\end{array}$ & $\begin{array}{l}\text { Energy } \\
\text { value, } \mathrm{kcal} / \mathrm{kJ}\end{array}$ \\
\hline $\begin{array}{l}\text { Milk-cereal drink 3.2\% } \\
\text { fat }\end{array}$ & 3.2 & 6.5 & 6.57 & $81.08 / 339.2$ \\
\hline $\begin{array}{l}\text { Milk-cereal drink 2.5\% } \\
\text { fat }\end{array}$ & 2.5 & 5.482 & 5.72 & $73.54 / 307.7$ \\
\hline $\begin{array}{l}\text { Milk-cereal drink 1.0\% } \\
\text { fat }\end{array}$ & 1.0 & 4.792 & 7.0 & $65.72 / 274.9$ \\
\hline
\end{tabular}

Milk proteins (caseins) are biologically complete, as they contain all the essential amino acids. Milk fats (lipids) are the most valuable energy sources for the body. The developed fermented milk drinks from goat milk have a high nutritional and energy value due to the introduction of fruit, berry, and cereal components into their composition.

\section{Studying the storage capacity of fermented milk drinks from goat milk}

To substantiate the shelf life, the influence of the presence of cereal and fruit and berry fillers on the organoleptic, physicochemical, and microbiological indicators of fermented milk drinks from goat milk during their storage was studied.

Storage tests were carried out for 15 days. 
After the end of the fermentation process, the products were packed into plastic cups with a capacity of $400 \mathrm{ml}$ and placed in a chamber with a temperature of $(4 \pm 1){ }^{\circ} \mathrm{C}$, where the storage process was carried out. The consistency, taste, and smell of fermented milk drinks with vegetable fillers remain at a high level for 15 days of storage and are $4.8 \pm 0.2$ points. During storage, the titratable acidity of the produced fermented milk drinks was measured.

The research results are presented in Table 6.

Table 6. Change in titratable acidity of fermented milk drinks with vegetable fillers during storage, ${ }^{\circ} \mathrm{T}$

\begin{tabular}{|l|l|l|l|l|l|l|}
\hline $\begin{array}{l}\text { Index of titratable } \\
\text { acidity, }{ }^{\circ} T\end{array}$ & 0 & 3 & 6 & 9 & 12 & 15 \\
\cline { 2 - 7 } & & & & & & \\
\hline $\begin{array}{l}\text { Fermented milk } \\
\text { drink with fruit and } \\
\text { berry filling }\end{array}$ & $90 \pm 2$ & $95 \pm 2$ & $101 \pm 2$ & $106 \pm 2$ & $110 \pm 2$ & $118 \pm 2$ \\
\hline Milk-cereal drink & $90 \pm 2$ & $94 \pm 2$ & $100 \pm 2$ & $106 \pm 2$ & $110 \pm 2$ & $116 \pm 2$ \\
\hline
\end{tabular}

As a result of the study, it was found that the accumulation of lactic acid in drinks does not stop, and the titratable acidity reaches $118 \pm 2{ }^{\circ} \mathrm{T}$ by the end of the shelf life. The addition of plant components contributes to a slight increase in the acidity of the product during storage.

Due to bifidobacteria's high activity, the total number of microorganisms changes insignificantly and throughout the entire storage period corresponds to the norm for fermented milk drinks: pathogenic microorganisms, incl. Salmonella, BGKP (coliforms), S. aureus are absent in ready-made drinks.

\section{Calculation of the recipe for fermented milk drinks based on goat milk}

The raw materials for producing fermented milk drinks are whole and skim goat milk, starter culture, and vegetable filler.

The amount of required raw materials and other materials is calculated based on the product calculation for a given product type.

Delivery costs of starter cultures - $2 \%$ of the cost of raw materials and other materials. The calculation of the cost of raw materials and other materials is presented in Table 7.

With the given ingredients and restrictions, the recipe composition and the cost of the product were determined.

Table 7. Information matrix of data for optimizing the formulation of a fermented milk drink with a filler

\begin{tabular}{|c|c|c|c|c|c|c|}
\hline \multirow[t]{2}{*}{ Ingredients } & \multirow[t]{2}{*}{$X_{i}$} & \multicolumn{4}{|c|}{ Mass fraction, $\%$} & \multirow{2}{*}{$\begin{array}{c}\text { Price, } \\
\text { tenge/ } k g\end{array}$} \\
\hline & & fat & protein & $\begin{array}{c}\text { dry } \\
\text { substances }\end{array}$ & water & \\
\hline Whole goat milk & $\mathrm{X}_{1}$ & 3.9 & 3.3 & 8.14 & 84.56 & 200 \\
\hline Skimmed goat milk & $\mathrm{X}_{2}$ & 0.05 & 3,2 & 7.8 & 88.95 & 80 \\
\hline $\begin{array}{l}\text { Filler: ozonized berry } \\
\text { (or flour) mixture }\end{array}$ & $\mathrm{X}_{3}$ & 0.2 & 0.4 & 15.0 & 84.4 & 800 \\
\hline Leaven & $\mathrm{X}_{4}$ & 0.0 & 0.0 & 0.0 & 0.0 & 541667 \\
\hline $\begin{array}{l}\text { The composition of } \\
\text { the fermented milk } \\
\text { drink }\end{array}$ & & 2.5 & 3.3 & 9.2 & 87.5 & $\min F(x)$ \\
\hline
\end{tabular}

Starter culture of thermophilic lactic acid sticks: $24 \mathrm{~g}$ cost 3650 tenge, therefore $1 \mathrm{~kg}=$ $3650 \cdot 41.6=151840$ tenge, 
bifidobacteria:

$1 \mathrm{~g}-650$ tenge, $1 \mathrm{~kg}=650 \cdot 1000=650.000$ tenge.

216667 tenge costs $1 / 3 \mathrm{~kg}$ of sourdough.

Cost of $1 \mathrm{~kg}$ of starter culture:

$151840 \cdot 2=303680 ; 303680+216667=541667$ tenge.

Based on the information matrix of data, a system of linear balance equations for fat, protein, dry substances, water, and the mass of fermented milk drinks are formed (Table 8).

Table 8. System of linear balance equations

\begin{tabular}{|l|c|}
\hline \multicolumn{1}{|c|}{ Balance by } & Equations and Constraints \\
\hline Fat & $\left(3.9 \cdot \mathrm{X}_{1}+0.05 \cdot \mathrm{X}_{2}+0.2 \cdot \mathrm{X}_{3}+0.0 \cdot \mathrm{X}_{4}\right) / 100=2.5$ \\
\hline protein & $\left(3.3 \cdot \mathrm{X}_{1}+3.2 \cdot \mathrm{X}_{2}+0,4 \cdot \mathrm{X}_{3}+0.0 \cdot \mathrm{X}_{4}\right) / 100=3.3$ \\
\hline Dry substances & $\left(8.14 \cdot \mathrm{X}_{1}+7.8 \cdot \mathrm{X}_{2}+15 \cdot \mathrm{X}_{3}+0.0 \cdot \mathrm{X}_{4}\right) / 100=9.2$ \\
\hline Water & $\left(84.56 \cdot \mathrm{X}_{1}+88.95 \cdot \mathrm{X}_{2}+84.4 \cdot \mathrm{X}_{3}+0.0 \cdot \mathrm{X}_{4}\right) / 100=87.5$ \\
\hline Filler & $\mathrm{X}_{3}=10$ \\
\hline Leaven & $\mathrm{X}_{4}=0.03$ \\
\hline Weight & $\mathrm{X}_{1}+\mathrm{X}_{2}+\mathrm{X}_{3}+\mathrm{X}_{4}=100$ \\
\hline
\end{tabular}

The task is realized by solving a system of linear balance equations and constraints [5]. As a criterion for optimizing the recipe, the goal function was chosen - the minimum cost of the product, which will be written in the form:

$$
\operatorname{minF}(\mathrm{x})=\left(350 \cdot \mathrm{X}_{1}+160 \mathrm{X}_{2}+1200 \cdot \mathrm{X}_{3}+541667 \cdot \mathrm{X}_{4}\right)
$$

The solution of the system of linear balance equations is carried out in the MS Excel system using the add-in program "Solver" (Lisin, 2016) [5].

The calculation of the cost of raw materials and other materials is given in Table 9 .

Table 9. Calculation of the cost of raw materials and other materials

\begin{tabular}{|c|c|c|c|c|c|c|c|}
\hline \multirow[t]{2}{*}{ Ingredients } & \multirow[t]{2}{*}{$X_{i}$} & \multirow{2}{*}{$\begin{array}{l}\text { Recipe } \\
, \mathrm{kg}\end{array}$} & \multicolumn{4}{|c|}{ Mass fraction, $\%$} & \multirow{2}{*}{$\begin{array}{c}\text { Price, } \\
\text { tenge/ } \mathrm{kg}\end{array}$} \\
\hline & & & fat & protein & $\begin{array}{c}\text { dry } \\
\text { substances }\end{array}$ & water & \\
\hline Whole goat milk & $\mathrm{X}_{1}$ & 56 & 3.9 & 3.3 & 8.9 & 83.4 & 200 \\
\hline Skimmed goat milk & $\mathrm{X}_{2}$ & 34 & 0.05 & 3.2 & 8.2 & 88.55 & 80 \\
\hline $\begin{array}{l}\text { Filling: ozonized } \\
\text { mixture of berries } \\
\text { (flour) }\end{array}$ & $\mathrm{X}_{3}$ & 10 & 0.2 & 0.4 & 16 & 83.4 & 800 \\
\hline Leaven & $\mathrm{X}_{4}$ & 0.03 & 0 & 0 & 0 & 0 & 541667 \\
\hline Total, kg & & 100.03 & & & & & \\
\hline $\begin{array}{l}\text { Goal function, } \\
\text { tenge }\end{array}$ & & \multicolumn{5}{|c|}{ prime cost, tenge / $100 \mathrm{~kg}$} & 37523 \\
\hline Balance Equations & & & 2.5 & 3.3 & 9.2 & 87.5 & 37523 \\
\hline
\end{tabular}




\section{Conclusions}

The findings reported here suggest that:

1. The nutritional and energy value for ready-made fermented milk drinks from goat milk with vegetable fillers has been determined.

2. An information matrix was compiled based on which systems of linear equations were obtained to optimize the formulation of fermented milk drinks from goat milk with vegetable fillers.

3. The technological process for the production of fermented milk drinks consists of the following operations: acceptance and preparation of raw materials; transitional storage, which was carried out at a temperature of $4 \pm 2{ }^{\circ} \mathrm{C}$; normalization at a temperature of $(60 \pm 5)$ ${ }^{\circ} \mathrm{C}$, pasteurization at a temperature of $(85 \pm 2){ }^{\circ} \mathrm{C}$ with an exposure of 8 to 10 minutes, or 90 ${ }^{\circ} \mathrm{C}$ with an exposure of 20 seconds, ozonation of goat milk for $10 \mathrm{~min}$ at an ozone concentration of $80 \mathrm{mg} / \mathrm{m}^{3}$, ozonation of fruit, berry and cereal fillers before adding to the drink for 10 minutes at $85 \mathrm{mg} / \mathrm{m}^{3}$ ozone; cooling milk to fermentation temperature $\left(37^{\circ} \mathrm{C}\right)$; fermentation of mixtures - at a temperature of $37^{\circ} \mathrm{C}$ for $8-10$ hours, ripening - at $12{ }^{\circ} \mathrm{C}-14$ ${ }^{\circ} \mathrm{C}$ for 6-8 hours, packaging, cooling of the obtained fermented milk drinks to a temperature of $(4 \pm 2){ }^{\circ} \mathrm{C}$ and storage up to $14-15$ days.

\section{References}

1. https: //kartaslov.ru/value-words/nutritional value, Access source: Internet resource, Date of treatment: 09/10/2020

2. A.A. Shunekeeva, M.K. Alimardanova, Method for producing a fermented milk drink analog of ayran from goat's milk, Patent RK 4956, Bul. 20, 6 p, (2020)

3. A.A. Shunekeeva, M.K. Alimardanova, Method for the production of a national milkcereal drink, Patent RK 4965, Bul. 20, 6 p, (2020)

4. V.V. Kryuchkova, Technology of milk and dairy products: textbook, Donskoy GAU, 232 p (2018)

5. P.A. Lisin, Computer technologies in industrial processes of food industry, SPb.: Lan, $256 \mathrm{p},(2016)$

6. TRCU 033/2013 Technical Regulations of the Customs Union On the safety of milk and dairy products, Access source: Internet resource, Date of access: 10.09.2020, http://docs.cntd.ru/document/902320560

7. TRCU 021/2011 of the Customs Union On food safety, Access source: Internet resource, Date of access: 10.09.2020, http://docs.cntd.ru/document/902320560 